Al-Bayyinah: Journal of Islamic Law- ISSN: 1979-7486 (p); 2580-5088 (e) VolumeVII Number 2, pp. 101- 116

\title{
TINJAUAN HUKUM ISLAM TERHADAP NILAI SAKRALITAS BUDAYA MAPPANRE' TEMME DALAM PERKAWINAN ADAT BUGIS BONE
}

\section{Sadiani}

(Dosen Fakultas Syariah dan Hukum IAIN Palangkaraya)

\section{Abstract}

Mappanré temme in Bugis Bone customary marriage is a form of gratitude and gratitude has been able to read and complete the Qur'an. The ability to read the Qur'an is expected to be able to be practiced in navigating the household ark. The implementation of this culture has values that contain wisdom and purpose. The value of cultural sacredness mappanré temme (khataman alQur'an) includes; the value of worship, the value of sennusennungeng, and the people's belief in the imperfection of marriage if they do not implement mappanré temme. From the value of the sacred, mappanré temme (khataman al-Qur'an) in the review of Islamic law is a culture that may be carried out and is a urf that is valid by looking at the wisdom and purpose of its implementation.

Kata Kunci: Hukum Islam, sakralitas, Mappanré Temme, perkawinan, Bugis

\section{A. Latar Belakang}

Pelaksanaan upacara perkawinan masyarakat Bugis Bone pada umumnya dilakukan melalui 4 tahapan, yakni segala upacara yang terdapat pada upacara sebelum/pra akad nikah, persiapan akad nikah, upacara akad nikah, dan sesudah/pasca akad nikah. Pelaksanaan budaya ini dalam kaitannya dengan perkawinan masyarakat Bugis Bone umumnya dilaksanakan 
pada saat "tudang penni (duduk di malam hari)", yakni pada saat sebelum pelaksanaan upacara "mappaci".

Menelusuri latar belakang tradisi mappanré temme (khataman al-Qur'an), tidak lepas dari islamisasi di Sulawesi Selatan yang bermula di kerajaan Gowa pada tahun 1607. Setelah Islam diterima oleh Sultan Alauddin di masjid Tallo Mulai saat itulah Kerajaan Gowa-Tallo memproklamirkan Islam sebagai agama resmi kerajaan dan menjadi pusat penyebaran agama Islam terbesar di Sulawesi Selatan.

Pendidikan agama secara tradisional dimulai pada usia kanak-kanak. Anak-anak tersebut selain belajar di mesjid, biasanya juga dititipkan belajar di rumah seorang guru agama. Mereka akan belajar tata cara sholat lima waktu dan cara mengaji al-Qur'an. Pelajaran mengaji tidak dimulai langsung dengan membaca kitab al-Qur'an yang lengkap, melainkan dengan mengaji "al-Qur'an kecil”, yang berisi juz ke-30 yang terdiri atas surah-surah pendek dan bila telah lancar maka barulah pindah pada "al-Qur'an besar". Setelah sang anak menyelesaikan tahap pertama dari pelajaran agama tersebut, diadakanlah perayaan yang disebut mappanré temme. ${ }^{3}$

Khataman al-Qur'an merupakan sebuah tradisi bagi orang yang tamat mengaji. Pelaksanaan tradisi ini dalam masyarakat Bugis dilaksanakan pada 2 tahap, yakni pada saat setelah putra-putri tamat mengaji dan saat akan melangsungkan perkawinan. Tradisi khataman al-Qur'an yang diyakini

${ }^{1}$ Tudang penni secara harfiah berarti duduk pada malam hari. Sedangkan secara terminologi, Tudang penni adalah berkumpulnya segenap rumpun keluarga pada malam perkawinan. Lihat Syarifuddin Latif, Fikih Perkawinan Bugis Tellumpoccoe dalam Perspektif Hukum Islam, (Disertasi Doktor, Program Pascasarjana UIN Alauddin, Makassar, 2009), h. 152.

${ }^{2}$ Mappacci (mengoleskan daun pacar) berakar dari kata pacci secara harfiah dapat diartikan dengan membersihkan diri. Sedangkan secara istilah mappacci adalah proses penyucian jiwa terhadap calon mempelai lakilaki dan calon mempelai perempuan yang akan berumah tangga dengan menngunakan daun pacar. Secara filosofis berarti pensucian diri secara batiniyah dan jasmaniyah sehingga dapat menjalin kehidupan rumah tangga dengan hati bersih. Lihat Syarifuddin Latif, Fikih Perkawinan Bugis Tellumpoccoe, h. 155.

${ }^{3}$ Christians Pelras, The Bugis. Terj. Abdul Rahman Abu Dkk, Manusia Bugis (Cet.1; Jakarta: Forum Jakarta-Paris, EFEO, 2006), h. 215. 
masyarakat Bugis Bone memiliki nilai sacral dan sebagai rasa syukur terhadap pencapaian putra-putri yang mampu menamatkan al-Qur'an. Hal ini merupakan pencapaian yang bersifat religius maka di tengah masyarakat cenderung menggabungkan tradisi ini dalam prosesi perkawinan pada masyarakat Kab. Bone.

\section{B. Rumusan Masalah} berikut:

Adapun rumuskan masalah penelitian ini sebagai

1. Nilai sakralitas apa yang terdapat dalam budaya mappanré temme pada perkawinan adat Bugis Bone?

2. Apa tinjauan hukum Islam terhadap nilai sakralitas budaya mappanré temme dalam perkawinan adat Bugis Bone?

\section{Tujuan dan Kegunaan Penelitian}

Adapun tujuan penelitian ini adalah untuk mengetahui nilai sakralitas budaya mappanré temme dan ntuk mengetahui tinjauan hukum Islam terhadap nilai sakralitas budaya mappanré temme dalam perkawinan adat Bugis Bone. Sedangkan kegunaan penelitian, yakni hasil penelitian diharapkan dapat memberi sumbangsi dan kontribusi terhadap perkembangan ilmu pengetahuan pada umumnya dan ilmu keislaman pada khususnya (kegunaan ilmiah), serta diharapkan dapat memberi sumbangsi pemikiran dan masukan terhadap individu dan instansi terkait dalam merumuskan kebijakan pembangunan masyarakat, bangsa, negara, dan agama (kegunaan praktis).

\section{Metodologi Penelitian}

Penelitian ini termasuk penelitian lapangan berjenis kualitatif dengan menggunakan pendekatan sosiologis, pendekatan teologis normatif, dan pendekatan antropologis. Adapun sumber data primer yang digunakan adalah hasil penelitian dan bahan-bahan pustaka yang relevan dengan masalah penelitian. Adapun instrumen penelitian adalah penulis sendiri. 


\section{E. Hasil Pembahasan}

\section{Kajian Pustaka}

\section{a. Pengertian dan Dasar Hukum Mappanré Temme}

Mappanré dalam bahasa Bugis berarti memberi makan, sedangkan temme ialah orang yang tamat mengaji atau khatam al-Qur'an. Dalam Glosarium Sulawesi Selatan, mappanré temme diartikan sebagai proses pengadaan perjamuan sehubungan dengan khataman alQur'an. Pada intinya mappanre temme' adalah sebuah prosesi yang memberi apresiasi terhadap anak laki-laki atau perempuan yang telah tamat mengaji atau khatam alQur'an. ${ }^{4}$

Mappanré dalam bahasa Bugis berarti memberi makan, sedangkan temme ialah orang yang tamat mengaji atau khatam al-Qur'an. Dalam Glosarium Sulawesi Selatan, mappanré temme diartikan sebagai proses pengadaan perjamuan sehubungan dengan khataman alQur'an. Pada intinya mappanre temme' adalah sebuah prosesi yang memberi apresiasi terhadap anak laki-laki atau perempuan yang telah tamat mengaji atau khatam alQur'an. ${ }^{5}$

Khataman al-Qur'an dilakukan dengan dua cara, yaitu; pertama, calon mempelai yang telah berpakaian pengantin duduk dipelaminan mendengarkan dan menunjuk ayat-ayat al-Qur'an yang dibaca oleh imam atau guru mengajinya. Kedua adalah calon pengantin membaca ayat-ayat al-Qur' an sedangkan imam atau guru mengajinya mendengarkan ayat-ayat al-Qur'an dibacakan calon mempelai.

Khataman al-Qur'an lahir dari bentuk islamisasi masyarakat Bugis Bone didasarkan pada adanya perintah membaca al-Qur'an sebagaimana dalam QS al-Alaq/ 96: 1-5:

${ }^{4}$ Suriadi Mappangara, Glosarium Sulawesi Selatan (Cet. I; Makassar: BPNST Makassar, 2007), h. 274.

${ }^{5}$ Suriadi Mappangara, Glosarium Sulawesi Selatan, h. 274. 


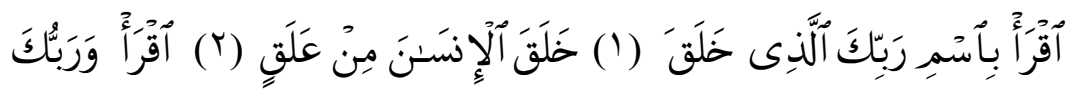

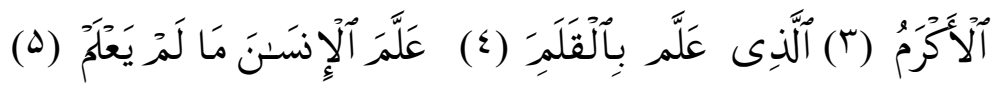

Terjemahnya:

Bacalah dengan (menyebut) nama Tuhanmu yang menciptakan, Dia telah menciptakan manusia dari segumpal darah. Bacalah, dan Tuhanmulah yang Maha pemurah, yang mengajar (manusia) dengan perantaran kalam. Dia mengajarkan kepada manusia apa yang tidak diketahuinya. $^{6}$

Adapun perintah membaca al-Qur'an yang terdapat dalam hadis Rasulullah saw adalah sebagi berikut:

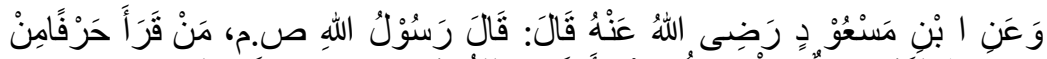

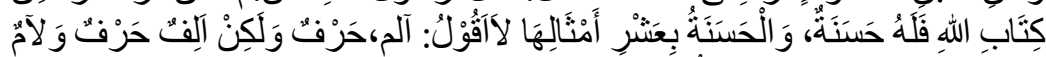

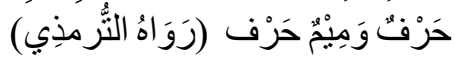

Artinya:

Dari Ibnu Mas'ud ia berkata: Rasulullah saw. Bersabda: "barangsiapa yang membaca satu huruf dari kitab Allah (al-Qur'an) maka akan memperoleh satu kebaikan. Setiap satu kebaikan dibalas dengan sepuluh kali lipat. Aku tidak mengatakan: 'Alif Laam Miim' itu satu huruf, tetapi 'alif' satu huruf, 'laam' satu huruf, dan 'miim' satu huruf'. '

\section{b. Tujuan dan Hikmah Mappanré Temme}

Prosesi mappanré temme yang dilakukan adalah membaca ayat suci al-Qur'an, sehingga tujuan dari prosesi ini tidak terlepas dari pada tujuan dan hikmah membaca alQur'an itu sendiri.

Adanya upacara khataman al-Qur'an akan mempererat hubungan silatturrahim baik kepada sesama

\footnotetext{
${ }^{6}$ Departemen Agama RI, Mushaf Al-Qur'an Terjemah (Jakarta: Al-Huda Kelompok Gema Insani, 2002), h. 598.

${ }^{7}$ Imam Nawawi, Riyadhus Shalihin, Terj. Achmad Sunarto (Cet.IV; Jakarta:Pustaka Amani, 1999), h. 118-119.
} 
keluarga maupun antara keluarga putra putri yang tamat mengaji dengan guru mengaji. Hal ini dapat di lihat dengan adanya upacara ini, akan dihadiri dan disaksikan oleh keluarga, bahwasanya putra putri mereka memang telah berhasil menamatkan al-Qur'an 30 juz. Hal tersebut merupakan salah satu bentuk keberhasilan sehingga menjadi kesyukuran jika apa yang telah dibaca (al-Qur'an) dapat diaplikasikan nantinya dalam kehidupan sehari-hari dan akan menjadi pedoman dalam berperilaku.

Dengan perayaan khataman al-Qur'an yang dilakukan pada saat putra-putri yang telah tamat mengaji merupakan salah satu bentuk penghargaan seorang murid terhadap guru mengajinya dan saat itu pula menjadi kesempatan bagi para keluarga untuk berkumpul di rumah orang tua murid sembari melihat kemampuan anak tersebut mengaji yang kemudian dilanjutkan santap bersama. ${ }^{8}$ Di antara tujuan dari upacara ini adalah agar murid yang dahulu menjadikan tanggung jawab seorang guru, setelah melakukan khataman al-Qur' an maka murid ini tidak akan menjadi tanggungan guru mengaji lagi.

Sebagaimana telah dipaparkan sebelumnya bahwa upacara khataman al-Qur'an dilakukan dalam dua tahap. Pertama, pada saat putra putri telah selesai menamatkan 30 Juz. Kedua, pada saat putra-putri masyarakat Bugis akan melangsungkan perkawinan. Sehubungan dengan penggabungan prosesi ini ke dalam upacara perkawinan yang biasanya dilaksanakan pada saat "tudang penni" sebelum acara "mappacci" (mengoleskan daun pacar), tentu terdapat hikmah yang relevan untuk kedua mempelai yang akan melangsungkan perkawinan. Di antara hikmah upacara tersebut yang paling penting adalah untuk mensucikan jiwa, menentramkan hati calon mempelai sebelum mengarungi bahtera rumah tangga.

Melihat keutamaan-keutamaan membaca al-Qur'an, dalam kaitannya dengan budaya mappanré temme (khataman al-Qur'an) ini, dapat dinyatakan bahwa pelaksanaan budaya mappanré temme (khataman al-

${ }^{8}$ Christians Pelras, The Bugis, h. 213. 
Qur'an) dalam perkawinan bertujuan agar apa yang telah dibaca dapat diamalkan dalam mengarungi bahtera kehidupan berumah tangga nantinya, di samping itu pelaksanaan budaya ini sebagai bentuk rasa syukur karena telah mampu membaca dan menamatkan al-Qur'an.

\section{Pembahasan}

a. Nilai Sakralitas Budaya Mappanré Temme dalam

\section{Perkawinan Adat Bugis Bone}

Dalam rangkaian prosesi perkawinan masyarakat bugis Bone terdapat nilai-nilai yang oleh masyarakat Bugis Bone dianggap perlu dijunjung tinggi, meliputi: nilai kekerabatan, status sosial, penghargaan terhadap perempuan, gotong royong, dan nilai sakralitas. Meskipun dalam kenyataannya budaya perkawinan masyarakat Bugis Bone seiring dengan perkembangan zaman telah mengalami banyak perubahan dalam pelaksanaannya, namun hal itu tidak mengurangi dari pada nilai-nilai yang ada dalam rangkaian prosesi perkawinan.

Dalam proses perkawinan masyarakat Bugis, ada nilai yang terkandung dalam setiap prosesi, antara lain: nilai kekerabatan, status sosial, penghargaan terhadap perempuan, gotong-royong, dan nilai sacral.

Nilai sakralitas dalam budaya perkawinan masyarakat Bugis Bone terlihat jelas dari pelaksanaan berbagai macam ritual-ritual khusus seperti mandi tolak bala, pembacaan barzanji, acara mappanré temme, acara mappacci, dan lain sebagainya. Ritual-ritual tersebut oleh masyarakat Bugis Bone dianggap sakral dan bertujuan untuk memohon keselamatan kepada Allah swt. Terlebih pelaksanaan budaya mappanré temme dilaksanakan sebagai bentuk rasa syukur dan memohon petunjuk dengan doa-doa yang telah dipersembahkan pada biasanya oleh imam-imam/pemuka agama.

Keyakinan masyarakat Bugis Bone, bila dalam pelaksanaan perkawinan telah meninggalkan salah satu budaya, maka perkawinan dipandang tidak sempurna dan keluarga/kerabat merasa malu. Hal ini dapat dilihat dalam pelaksanaan budaya perkawinan terkhusus dalam acara 
tudang penni dirangkaikan 3 upacara yang satu sama lain saling berkaitan yang dalam kenyataannya sudah tidak terpisahkan karena sudah menjadi tradisi dalam masyarakat Bugis Bone, yaitu mabbarazanji, mappanré temme (khataman al-Qur'an), dan Mappacci.

Mappanré temme (khataman al-Qur'an) merupakan tradisi/budaya turun temurun dalam masyarakat Bugis Bone. Sebagian masyarakat memandang pelaksanaan budaya ini memiliki nilai-nilai tersendiri di dalamnya. Di samping merupakan budaya, mappanré temme (khataman al-Qur'an) juga memiliki nilai ibadah di dalamnya. Sumber dari budaya ini yang dirangkaikan dengan prosesi perkawinan adalah bersamaan dengan budaya mappacci. Hal ini dapat dilihat mappanré temme (khataman al-Qur'an) dan mappacci dilakukan sebagai satu rangkaian dalam prosesi tudang penni.

Munculnya budaya mappanré temme (khataman alQur'an), sebagian dalam masyarakat Bugis Bone menganggap bahwa budaya ini dilakukan sebagai upaya para ulama untuk menghindari budaya-budaya yang mengarah kepada kemusyrikan maka di masukkanlah budaya yang bernuansa Islami ke dalam prosesi perkawinan. Memasukkan budaya yang bernuansa Islam ke dalam prosesi perkawinan merupakan salah satu Syiar Islam di Kabupaten Bone.

Tata cara pelaksanaan mappanré temme (khataman alQur'an) pada hakikatnya adalah calon pengantin yang diperkenankan untuk membacakan ayat-ayat yang telah ditentukan itu dan bukanlah Imam/guru mengaji, akan tetapi dalam kenyataannya sering yang membacakan itu adalah Imam/guru mengaji dengan alasan bahwa agar keluarga/kerabat yang menyaksikan pelaksanaan budaya ini tidak merasa malu karena calon mempelai tidak lancar bacaannya. Hal ini menunjukkan bahwa untuk menjaga eksistensi budaya yang bernuansa Islami ini perlu dilakukan dengan tata cara yang sesuai dari tujuan pelaksanan budaya ini, yakni untuk menunjukkan bahwa calon pengantin memang sudah tamat membaca al-Qur'an dan mampu untuk membacanya sehingga kelak dapat menjadi imam yang baik bagi keluarganya. 
Setelah pembacaan ayat-ayat al-Qur'an tersebut selesai, kemudian calon pengantin berjabat tangan dengan gurunya disusul dengan keluarga, kerabat yang hadir serta doa-doa dipanjatkan sebagai rasa syukur atas peristiwa ini dan pertanda suksesnya calon pengantin menyelesaikan pembacaan al-Qur'annya sebanyak 30 juz serta dilanjutkan makan bersama dengan hidangan yang tersedia.

Mappanré temme sebagai salah satu budaya yang bersifat religius dalam masyarakat Bugis Bone pada dasarnya dilakukan terpisah dengan budaya perkawinan. Namun seiring berjalannya waktu budaya ini telah menjadi rangkaian prosesi dalam perkawinan, meskipun sudah dilakukan sebelumnya, karena mappanré temme memiliki nilai sakralitas yang bersifat keagamaan, sehingga budaya seperti ini sulit untuk dihilangkan. Sebagaimana yang disampaikan oleh Dg. Manessa seorang Budayawan Bugis di Palangkaraya sebagai berikut:

'Budaya mappanré temme (khataman al-Qur'an) mengandung nilai sakralitas. Nilai sakralitas di sini dapat dipahami dengan nilai-nilai religius/keagamaan di dalam pelaksanaan budaya ini. Dengan demikian masyarakat cenderung menggabungkan ke dalam prosesi perkawinan, dengan asumsi bahwa upacara perkawinan merupakan upacara yang sakral dan religius sehingga dengan menggabungkan mappanré temme (khataman alQur'an) dalam perkawinan akan menampakkan bahwa calon pengantin merupakan makhluk yang beragama".

Lebih jelasnya, alasan bahwa nilai sakralitas dalam pelaksanaan mappanré temme sehingga dirangkaikan dengan prosesi perkawinan, antara lain:

1. Adanya nilai ibadah

2. Adanya nilai sennu-sennungeng rideceng'e (kecintaan akan kebaikan)

3. Keyakinan masyarakat akan ketidaksempurnaan perkawinan bila tidak melaksanakan mappanré temme (khataman al-Qur'an).

\footnotetext{
${ }^{9}$ Dg. Manessa, Budayawan Bugis Palangkaraya, Wawancara, 30
} April 2018. 
Selain itu, mappanré temme (khataman al-Qur'an) juga mengandung nilai sebagai pertanda adanya rasa syukur keluarga terhadap anak yang telah berhasil menamatkan alQur'an. Pada umumnya dalam masyarakat Bugis Bone untuk mempertegas rasa syukur itu maka dilkasanakanlah syukuran dengan mempersiapkan berbagai jenis makanan-makanan khas Bugis, seperti sokko (beras ketan), manu' (ayam) dan beppa-beppa (kue-kue).

Pelaksanaan mappanré temme (khataman al-Qur'an) ini dirangkaikan dengan prosesi perkawinan bertujuan untuk efisiensi waktu dan karena pada proses perkawinan terkhusus pada malam tudang penni (duduk di malam hari) disediakan berbagai hidangan khas Bugis, maka dirangkaikanlah juga mappanré temme (khataman al-Qur'an) agar keluarga tidak kesusahan dalam mempersiapkan hidangan, maka cukup dilaksanakan dengan satu rangkaian saja, yakni pada acara tudang penni dengan rangkaian prosesi mabbarazanji dan mappacci.

Tradisi mappanré temme (khataman al-Qur'an) jika dicermati dari segi pelaksanaan dari awal hingga akhir tidak terlepas dari kontribusi manusia sebagai makhluk beragama. Mulai dari persiapan kue-kue, sokko (beras ketan), dan manu' (ayam), al-Qur'an dan lain sebagainya, hingga pada tahap pelaksanaan mappanré temme itu sendiri. Serangkaian kegiatan itu, merupakan seluruh konsep kegiatan yang tidak terlepas dari nilai religius yang mengandung nilai sakralitas.

Nilai sakral ini dapat di dasarkan pada adanya keharusan (mappanré temme) untuk dilaksanakan oleh calon mempelai yang akan melangsungkan perkawinan, karena dianggap sudah menjadi budaya yang bahkan dianggap sebagai suatu perkawinan tidak akan sempurna bila tidak dilaksanakan mappanré temme (khataman al-Qur'an).

b. Tinjauan Hukum Islam Terhadap Nilai Sakralitas Budaya Mappanré Temme (Khataman al-Qur'an) dalam Perkawinan Adat Bugis Bone.

Penggolongan adat dari segi penilaian baik dan buruk, maka adat atau urfterbagi kepada: 
1. Urf yang shahih, yaitu adat yang berulang ulang dilakukan dan diterima oleh orang banyak/masyarakat serta tidak bertentangan dengan agama, sopan santun, dan budaya yang luhur.

2. Urf yang fasid, yaitu adat yang yang berlaku dalam suatu tempat, yang meskipun sudah dilakukan secara merata dan diakui dalam masyarakat akan tetapi bertentangan dengan agama, Undang-Undang Negara dan sopan santun.

Kepatuhan masyarakat Bugis terhadap adat dan agama dilakukan secara bersamaan dan sama kuatnya. Dalam konsep pangadereng (undang-undang sosial) terdiri atas lima unsur yang saling mengukuhkan. Dua di antaranya adalah ade' (adat-istiadat) dan sara' (syariat Islam). Ade' merupakan salah satu aspek pangadereng yang mengatur pelaksanaan sistem norma dan aturan-aturan adat dalam kehidupan masyarakat Bugis. ${ }^{11}$

Salah satu bentuk dari pangadereng (adat istiadat) dari kehidupan masyarakat bugis pada umumnya dan masyarakat bugis Bone pada khususnya adalah abottingeng (perkawinan). Perkawinan ini merupakan bagian yang sangat integral dari kebudayaan masyarakat bugis yang di dalamnya berisi nilai-nilai budaya. Nilai budaya itulah yang ditampilkan dalam upacara ritual yang penuh dengan makna dan simbol. Salah satu budaya yang tidak sarak akan makna adalah pelaksanaan mappanré temme (khataman al-Qur'an) dalam perkawinan.

Melihat kenyataan dalam masyarakat Bugis Bone, mappanré temme (khataman al-Qur'an) ini sudah dilakukan secara turun temurun dan diterima masyarakat sehingga menurut hemat penulis hal tersebut dapat dikategorikan sebagai suatu budaya atau urf.

Kendatipun mappanré temme (khataman al-Qur'an) merupakan budaya yang lahir dari proses Islamisasi dengan

${ }^{10}$ Amir Syarifuddin, Ushul Fiqh (Cet. II; Jakarta: PT. Logos Wacana Ilmu, 2001), h. 368.

11 Mattulada, Latoa, (Cet.II; Ujung Pandang: Hasanuddin University Press; 1995), h. 342. 
nuansa Islam, namun tidak serta merta dalam pelaksanaannya akan memberi nilai yang hanya bersifat Islami saja, melainkan bisa saja mengarah pada hal yang bertentangan dengan Islam. Olehnya dipandang sebagai budaya yang perlu ditinjau dari sudut pandang hukum Islam tentang adanya nilai-nilai sakral dalam pelaksanaan budaya ini dan tentang bagaimana keberadaan budaya ini, apakah dalam pelaksanaannya merupakan urf yang bersifat shahih ataukah urf yang bersifat fasid.

Melihat realita yang ada di lapangan, masyarakat Bugis Bone telah menjadikan mappanré temme (khataman al-Qur'an) sebagai salah satu budaya yang dipandang baik untuk diamalkan, karena dalam pelaksanaanya terdapat nilainilai yang tidak hanya sekedar sebagai perayaan biasa, akan tetapi menjadi salah satu rangkaian puncak dari salah satu cara hidup orang muslim khusunya daerah Bugis Bone (membaca al-Qur'an) yang memiliki arti yang sangat mendalam.

Untuk mengetahui sudut pandang hukum Islam terhadap nilai sakralitas budaya mappanré temme (khataman al-Qur'an), maka perlu dianalisis dengan melihat pandangan para fuqaha terhadap Istinbath hukum yang menggunakan urf sebagai salah satu sumber hukum. Untuk lebih jelasnya akan paparkan sebagai berikut:

1. Adanya nilai ibadah yang terkandung dalam pelaksanaan budaya mappanré temme (khataman al-Qur'an). Ibadah yang dimaksudkan dengan adanya pelaksanaan mappanré temme (khataman al-Qur'an) adalah bilamana disertai dengan niat yang baik.

2. Adanya pelaksaaan mappanré temme (khataman alQur'an) dalam perkawinan dipandang sebagai budaya yang mengandung nilai sennu-sennungeng ri deceng'e (kecintaan akan kebaikan). Sebagian masyarakat memahami, terdapat sennu-sennungeng di dalamnya, yakni dipahami bahwa hal itu dilakukan dengan tujuan agar anak tersebut akan lancar dan tidak buta huruf dalam membaca al-Qur'an. Padahal hati ayam dengan kelancaran seseorang dalam membaca al-Qur'an tidak memiliki hubungan apapun dan tidak bisa diterima 
dengan akal sehat. Kepercayaan-kepercayaan seperti itulah yang perlu untuk diluruskan sehingga dalam pelaksanaan budaya mappanré temme (khataman alQur'an) jika dipahami terdapat nilai sakralitas yang dapahami karena sennu-sennungeng dengan akibat dari penyediaan makanan dan lainnya maka jika ditinjau dalam sudut pandang hukum Islam sangat jelas akan terjadi pertentangan. Olehnya itu untuk menjaga esensi dalam budaya ini perlu kehati-hatian dalam memahami makna sennu-sennungeng terhadap pelaksanaan budaya mappanré temme.

3. Adanya keyakinan masyarakat akan ketidaksempurnaan perkawinan bila ditinggalkan mappanré temme (khataman al-Qur'an). Kentalnya budaya yang ada dalam masyarakat Bugis Bone ditandai dengan pelaksanaan dan rentetan upacara yang masih terlaksana dengan tetap menjaga nilai-nilai yang ada didalamnya, karena bagi orang Bugis perkawinan merupakan satu bagian terpenting dalam kehidupannya. ${ }^{12}$ Dalam hukum perkawinan Islam keabsahan perkawinan dilihat dari terpenuhi atau tidaknya rukun dan syaratnya berdasarkan ketentuan yang ada dalam al-Qur'an dan sunnah. Masyarakat Bugis Bone sebagai masyarakat yang mayoritas pemeluk agama Islam tetap meyakini dan menjalankan Rukun dan syarat perkawinan yang telah ditetapkan oleh syariat, namun tidak bisa dipungkiri juga bahwa masyarakat Bugis Bone adalah masyarakat yang masih menjunjung tinggi nilai-nilai adat yang ada.

Keberadaan budaya mappanré temme (khataman alQur'an) dalam perkawinan masyarakat Bugis Bone dipandang sebagai budaya yang baik dengan melihat nilai sakral yang ada didalamnya. Budaya ini diterima dan telah diamalkan dikalangan masyarakat. Tokoh agama dalam Bugis Bone membenarkan adanya budaya ini dan dapat

${ }^{12}$ Departemen Pendidikan dan Kebudayaan Direktorat Jenderal Kebudayaan Balai Kajian Sejarah dan Nilai Tradisional Ujung Pandang, Sawerigading :Media Informasi Sejarah dan Budaya Sulsel (Ujung Pandang: Balai Kajian Sejarah dan Nilai Tradisional, 1994), h.30. 
diamalkan dalam kehidupan masyarakat selama pelaksanaannya tidak bertentangan dengan Islam sehingga boleh saja dilaksanakan termasuk jika pelaksanaanya dirangkaiakan dengan prosesi perkawinan.

Dalam pemikiran hukum Islam (ilmu fiqh) para ahli hukum Islam banyak yang menerima berbagai macam praktek adat untuk dimasukkan ke dalam teori hukum Islam selama tidak bertentangan dengan prinsip-prinsip syari'at. Adat digunakan untuk memelihara kemaslahatan. Mereka melihat prinsip-prinsip adat sebagai salah satu sumber hukum Islam sekunder, dalam pengertian diaplikasikannya prinsip-prinsip adat tersebut hanya ketika sumber primer (alQur'an dan Hadis) tidak memberi jawaban terhadap permasalahan yang muncul. ${ }^{13}$

Pada hakikatnya pelaksanaan budaya mappanré temme (khataman al-Qur'an) yang dirangkaikan dengan prosesi perkawinan adalah sebagai syiar Islam. Di lain sisi pelaksanaan budaya ini juga merupakan tanda terima kasih dan rasa syukur seorang anak karena telah mampu menamatkan al-Qur'an. Menamatkan al-Qur'an menandakan seseorang mampu untuk membaca ayat suci al-Qur'an. Hal ini menjadi modal utama bagi umat Islam dalam memhami Islam yang kaffah.

Beberapa hikmah dan nilai sakralitas yang terkandung dari pelaksanaan budaya mappanré temme (khataman alQur'an) jika dipandang dari sudut pandang hukum Islam menggunakan kaidah urf, bahwasanya budaya tersebut tidak bertentangan dengan nash dan budaya dikatakan sebagai urf yang mengandung banyak maslahat. Dengan demikian menurut hemat penulis pelaksanaan mappanré temme (khataman al-Qur'an) merupakan urf yang besifat shahih.

${ }^{13}$ Ratno Lukito, Pergumulan antara Hukum Islam dan Adat di Indonesia (Jakarta: INIS, 1998), h. 6. 


\section{F. Penutup}

1. Budaya mappanré temme merupakan budaya yang lahir dari proses Islamisasi dalam masyarakat Bugis Bone. Penggabungan mappanré temme ke dalam rangkaian prosesi perkawinan adat Bugis Bone lahir bersamaan dengan prosesi mappaci yang dilaksanakan pada malam tudang penni. Hal ini merupakan salah satu bentuk syiar Islam pada masyarakat Bugis Bone. Mappanré temme merupakan budaya yang dilaksanakan setelah menamatkan al-Qur'an sebagai ungkapan rasa syukur dan tanda terima kasih putra-putri masyarakat Bugis Bone karena telah mampu menamatkan al-Qur'an.

2. Pelaksanaan Budaya mappanré temme yang dirangkaikan dengan pekawinan masyarakat Bugis Bone mengandung nilai sakral. Nilai sakral tersebut mencakup, nilai ibadah, nilai sennu-sennungeng rideceng'e (kecintaan akan kebaikan), dan adanya nilai ketidaksempurnanya perkawinan adat Bugis Bone bila tidak dilaksanakannya budaya mappanré temme (khataman al-Qur'an).

3. Islam memandang pelaksanaan budaya mappanré temme sebagai budaya boleh dilaksanakan selama pelaksanaannya tidak bertentangan dalam ketentuan yang ada dalam al-Qur'an dan sunnah, sehingga budaya mappanré temme merupakan budaya yang dipandang sebagai urf yang bersifat shahih. 


\section{G. Daftar Pustaka}

Departemen Agama RI. Mushaf Al-Qur'an Terjemah. Jakarta: Al-Huda Kelompok Gema Insani, 2002.

Departemen Pendidikan dan Kebudayaan Direktorat Jenderal Kebudayaan Balai Kajian Sejarah dan Nilai Tradisional Ujung Pandang, Sawerigading:Media Informasi Sejarah dan Budaya Sulsel. Ujung Pandang: Balai Kajian Sejarah dan Nilai Tradisional, 1994.

Latif, Syarifuddin. Fikih Perkawinan Bugis Tellumpoccoe dalam Perspektif Hukum Islam. Disertasi Doktor, Program Pascasarjana UIN Alauddin, Makassar, 2009.

Lukito, Ratno. Pergumulan antara Hukum Islam dan Adat di Indonesia. Jakarta: INIS,1998.

Mappangara, Suriadi. Glosarium Sulawesi Selatan. Cet. I; Makassar: BPNST Makassar, 2007.

Mattulada. Latoa. Cet.II; Ujung Pandang: Hasanuddin University Press; 1995.

Nawawi, Imam. Riyadhus Shalihin. Terj. Achmad Sunarto. Cet.IV; Jakarta:Pustaka Amani, 1999.

Pelras, Christians. The Bugis. Terj. Abdul Rahman Abu dkk. Manusia Bugis. Cet.1; Jakarta: Forum Jakarta-Paris, EFEO, 2006.

Syarifuddin, Amir. Ushul Fiqh. Cet. II; Jakarta: PT. Logos Wacana Ilmu, 2001. 